\title{
The Effect of Member Empowerment Program on The Welfare of The Credit Union Members in East Java
}

\author{
Nekhasius Agus Sunarjanto ${ }^{1,}$ Cicilia Erna Susilawati ${ }^{2,}$ Elisabeth \\ Supriharyanti ${ }^{3}$
}

\section{1,2,3 Widya Mandala Surabaya Catholic University}

sunarianto@ukwms.ac.id

\begin{abstract}
This study focuses on the institutions in the form of credit unions that provide credit loans to micro-businesses. The sample of this study consisted of 102 members of 15 different credit co-operatives in East Java as the research participants. The research objective of this study was to determine the effect of empowerment programs on the welfare of the members. The empowerment programs were divided into (1) educational, (2) training, (3) savings and loan, and (4) network development programs. The results showed that the empowerment programs through education and training programs had a significantly positive effect on increasing the welfare of the members, while the savings and loan programs as well as the network building program did not significantly affect the welfare of the members. This was possible because members who already had networks and received funding assistance would not succeed without good education and training programs. The research was expected to contribute academically in the development of savings and loan co-operative unions (CUs) and provide a foundation and solution for all CU administrators in developing the CUs, especially in improving the welfare of their members.

Keywords: Credit Union, member empowerment, and member welfare
\end{abstract}

JEL $\quad:$ M12

DOI : 10.24002/kinerja.v21i2.3137

Received : 01/30/2020 Reviewed: 07/10/2020 Final Version: 07/10/2020

\section{INTRODUCTION}

Poverty experienced by some Indonesians has become the main reason of implementing community empowerment. We can easily find various sources, both electronic and printed, of articles that discuss poverty. There have been various efforts made by the government to reduce the poverty level. The government, through various studies, continues to look for suitable solutions and to overcome this, encompassing social, political, economic and cultural aspects. In respect to this, credit co-operatives are engaged in the business of capital formation through continuous member savings, which is then lent to the members easily and quickly for productive purposes. 
Credit Union is intended for everyone who wants to create assets by saving with the hope that they will become more prosperous in the future. The concept of credit Union is very different from that of credit cards, car loans, home loans, and other credit items. A research study conducted by Dunn and Arbuckle (2001) shows that microcredit has a positive effect on the increasing microenterprise and household incomes and development of the individuals who receive the capital assistance. The increased household income which is due to work diversification will cause the spending on food and education to also increase, thereby increasing the family welfare.

With the birth of the Central Government Regulation in accordance with the mandate of the 1945 Constitution of the Republic of Indonesia, Law No. 25 of 1992 on Co-operatives. Co-operatives, as non-bank microfinance institutions, are able to carry out activities of microfinance which deal with the provision of financial services to their members by providing saving and loan services. Saving and loan service is a co-operative business activity to collect and distribute funds from and for co-operative members. The savings funds collected in co-operatives are working capital that can be used by co-operatives to be distributed as loans to members in need (Naeshela, 2016). One non-profit organization of this is credit union (CU). Credit Union, also known as credit co-operatives, is part of the Micro Finance Movement, which is touted by the United Nations (UN) in an effort to improve the social and economic conditions of the community. At present, there are more than 921 Primary Credit Unions in Indonesia, with the total number of CU members throughout Indonesia to be more than 2,353,704 people as of December 31, 2013 (Inkopdit, 2014).

CU growth had its peak in 1995 with 1,601 Primary CUs, but at the end of 2013 the number of CUs registered in the Inkopdit network was only 921 Primary CUs. The symptoms of this problem are interesting to explore further; what is the root of the sustainability problem of CU in Indonesia. Munaldus and Karlena (2015) said that the cause of the slow growth of $\mathrm{CU}$ was on the quality of human resources, in particular the lack of optimal supervisors or stakeholders, especially $50 \%$ dealing with the leading aspects and $50 \%$ about the managing aspects. As a non-profit organization, $\mathrm{CU}$ aims to empower the community by teaching the community to be independent, no longer waiting and relying on the helping hand of others in dealing with the social problems they face. However, CU must also maintain the sustainability of its business so that the empowerment activities can continue.

The form of empowerment of Co-operatives for Savings and Loans becomes an economic empowerment program that is able to realize the welfare of the community. For the capital beneficiaries, in this case micro, small and medium business actors in various business sectors, with the existence of co-operative funds channeled in the form of financing and intensive assistance, they realize that they have to improve their lives with an attitude, knowledge and skills for a better life. One of the positive effects of empowerment is an increase in output and performance which in this study is referred to as social performance.

Credit union member empowerment program consists of: (1) an educational program organized by $\mathrm{CU}$, (2) a training program for credit union members, (3) an empowerment program through savings and loans, (4) an empowerment program to facilitate members to establish business relationships with each other,

One positive impact of the credit union member empowerment program is the increase in the members' welfare measured by several attributes, namely (1) the perception of members on the CUs' concern for improving welfare, (2) the resolution of economic problems faced by members, (3) the programs to address members' business problems, (4) the positive impacts felt by members. 
With the research study background mentioned above, the research study titled: "The Effect of Member Empowerment Program on The Welfare of The Credit Union Members in East Java" is then initiated.

\section{LITERATURE REVIEW}

A loan and saving business is a co-operatives' activity to raise and distribute funds from and to co-operative members. Savings funds collected in co-operatives are working capital that can be used by co-operatives to be distributed as loans to members in need (Naeshela, 2016). One kind of a non-profit organization is a credit union (or CU). CU, also known as credit co-operatives, is part of the Movement Microfinance touted by the United Nations (UN) in an effort to improve the social and economic conditions of the community. At present, there are more than 921 Credit Primary Union in Indonesia, while the number of individual CU members throughout Indonesia is more than 2,353,704 people as of December 31, 2013 (Inkopdit, 2014).

Economic institutions play a large role for the community, not only banks, saving and loan co-operatives also help the community to manage and provide financial assistance to the community. It can be said that savings and loan co-operatives are institutions that move from and for the people. That is, the co-operative runs through funds from the community in the form of fund management for venture capital. Furthermore, the funds can be used by the public to borrow it. From these processes, the rules of savings and loan co-operatives applied are not as strict as those of banks. Co-operatives play a role in providing loan funds for people who have economies below the average and as business capital. In its service, a co-operative also does not prioritize services to members, but also the wider community

Based on the Act no. 17 of 2012 concerning co-operatives explained in Chapter III Article 5, two Co-operative values are expressed later become values that underlie cooperative activities and become values believed by co-operative members. Values that underlie co-operative activities are kinship, self-help, responsibility, democracy, equality, fairness and independence. Then, the values believed by the co-operative members themselves include honesty, openness, responsibility and care for others. Furthermore, in Chapter III Article 6, it is explained that the co-operative implements the Principles of Cooperative, which include:

1. Membership of co-operatives that are voluntary and open

2. Oversight by members is democratically carried out

3. Members actively participate in co-operative economic activities

4. Co-operatives are autonomous and independent business entities

5. Co-operatives organize education and training for members, Supervisors, Management and Employees and provide information to the public about the identity, activities and benefits of the co-operative.

6. The co-operative serves its members in a prime manner and strengthens the cooperative movement by cooperating through a network of activities at the local, national, regional and international levels. 
In its activities, savings and loan co-operatives are required to serve the depositing of funds and withdrawals from members in accordance with the agreed provisions. Each cooperative has a number of different provisions. In addition, saving and loan co-operatives also channel members' funds to be channeled back later in the future. Channeling is done in stages. Basically, co-operatives do manage savings funds. That way, it needs to be explained in detail about savings funds. The definition of savings fund itself is contained in the Act no. 9 of 1992, that funds entrusted to members, prospective members, other cooperatives, and/or Savings and Loans Co-operatives members are in the form of savings and term deposits.

\subsection{Member Empowerment}

Literally, the word "empowerment" means to make (someone) empowered. In terms of empowerment, it refers to efforts seriously made with the intention of improving the quality of human resources through planned and directed emancipation activities that are also controlled in a sustainable manner. Another term for empowerment is the meaningful development of human development efforts to become physically and mentally high quality human beings; people who have an increasingly solid sense of faith, adoration and knowledge (Sulistiyani, 2004). In addition to the aforementioned definition, empowerment can also be interpreted as a strategy to free people from ignorance, backwardness, poverty, so that they can develop in accordance with human dignity. Participatory approach is one of the main ways in empowerment, meaning that in the empowerment strategy, the community must be involved and included in the development process. Thus, empowerment is an effort to place human resources as subjects and not as objects in the development process.

Empowerment is a series of activities to strengthen or empower weak groups in society, including individuals who experience various poverty problems. The form of empowerment of Savings and Loans Co-operative funds becomes an economic empowerment program that is able to realize the welfare of the community. For the capital beneficiaries, in this case micro, small and medium business actors in various business sectors, with the existence of co-operative funds channeled in the form of financing and intensive assistance, they realize that they need to improve their lives with a better attitude, knowledge and skills for a better life. One of the positive effects of empowerment is an increase in output and performance, which in this study are referred to as social performance. Communities are able to take responsibility for their work, arrange it to suit individual needs and then carry it out without the intervention of others which impacts on the greater effectiveness. Continuous improvement is part of the management style of an organization that is applied starting from the top to the bottom level. Today's society has valuable targets and objectives to achieve, regardless of the level of output at any time. Establishing a supportive working relationship and identifying the measures of performance achieved are important (Foy, 1994).

The sustainability of a maintained CU will have an impact on the wider expansion of community empowerment activities. Empowerment is a process that essentially aims to realize "change". Expectations of an organization in principle tend to be directed at productivity, because empowerment will increase individual productivity, therefore the main concern is the flexibility and responsiveness of customers and quality is the goal of most modern organizations that adopt empowerment as a policy (Lowe, 1996). The form of empowerment undertaken by $\mathrm{CU}$ for its members can be demonstrated through: (1) educational programs organized by CU, (2) the spirit of togetherness established by CU, (3) CU policies established in the context of empowerment, (4) socialization of CU programs , (5) regular meetings of CU members, (6) empowerment program through savings and loans, 
(7) CU facilitates members to establish business relationships with each other, and (8) CU offers empowerment programs that members need. In relation to a dynamic community life, empowerment is more to be an effort to provide the ability, as well as an opportunity, for the community to take an active role in the development process.

\subsection{Members}

Welfare is an organized system of social services and institutions that aim to achieve satisfactory living standards and, as well as personal and social relationships, which enable co-operative members to develop all abilities and improve welfare, in harmony with family and community needs. The purpose of welfare is to guarantee human economic needs, health standards and decent living conditions, get the same opportunities as other citizens, increase the degree of self-esteem as high as possible, freedom of thought to do activities without interruption in accordance with human rights (Lowe, 1996).

According to Hudiyanto (2001), the achievement of increasing prosperity is a beneficial business goal in a co-operative business and is the work of activities within the framework of moral and social responsibility. Also, it is important to improve the living standards of its members, increase production and realize equitable income and equitable prosperity. Furthermore, Indonesian co-operatives must have and be based on the values of helping themselves, being accountable to themselves, democracy, equality, justice and solidarity.

CU can be said to be successful if it is able to improve the welfare of its members. The success of $\mathrm{CU}$ in increasing the welfare of members can be demonstrated through (1) the members' perceptions on the welfare improvement issue, (2) the CU's concern for members' problems, 3 ) the role of CU in overcoming members' economic difficulties, (4) the capacity of $\mathrm{CU}$ in holding a program to overcome members' problems, and (5) the capacity of $\mathrm{CU}$ to have a certain mechanism in solving problems, and (6) the CU runs programs that have a positive impact on its members.

The level of welfare is a concept used to express the quality of life of a community or individual in an area at a certain period of time. The concept of welfare or a sense of wellbeing that is owned is relative, depending on how each individual evaluates the welfare itself. Prosperity for someone with a certain level of income cannot also be said to prosper for others. According to Sulistiyani (2004), welfare is a subjective concept where everyone has different guidelines, goals and ways of life for the factors that determine the level of welfare.

\subsection{Hypothesis Development}

\subsubsection{The relationship between empowerment and the welfare of members}

Credit Union as a small-scale enterprise that has the goal of community welfare requires a well-established governance in its operational process. A good operational process will produce good financial performance and $\mathrm{CU}$ as an organization has good sustainability so that it can carry out wider community empowerment whose success is measured by the welfare of its members. In relation to dynamic community life, empowerment is an effort to provide the ability as well as opportunity for the community to take an active role in the development process. The success of $\mathrm{CU}$ in community empowerment shows that CU's performance in increasing the welfare of members is 
increasing and is expected to be more widespread (Lowe, 1996). Therefore, the hypothesis proposed in this study is:

H1 Educational program for members has a positive effect on the empowerment of members

H2 Training program for members has a positive effect on the welfare of members

H3 Savings and loans programs have a positive effect on the welfare of members

H4 The Network Development Program has a positive effect on the welfare of members.

\section{METHODOLOGY}

\subsection{Research Design}

Based on the formulation of the research problems and objectives, the researchers want to investigate the effect of empowering members on welfare. This study employs an analytic research design. Analytical research design is used to determine the causal relationship between two or more variables in an observational manner, where the relationships can be in the form of differences, correlations or influences.

\subsection{Data and Data Collection Procedures}

This study used data from financial statements issued by several credit co-operatives (CUs) in East Java. The research period was between 2011 and 2016. This period was taken because it was the closest period to the time when this research study was conducted.

\subsection{Definition of Operational}

\subsubsection{Empowerment of members (EM/Empowering)}

Empowerment of members is an effort undertaken by $\mathrm{CU}$ to strengthen or empower CU members. Variables used to measure member empowerment were educational programs, training programs, savings and loans programs and network development programs. Each variable was measured using the following indicators:

\begin{tabular}{|l|l|}
\hline Variables & Indicator \\
\hline \multirow{4}{*}{$\begin{array}{l}\text { Educational Programs } \\
\text { organized by CU }\end{array}$} & Educational programs for members \\
\cline { 2 - 2 } & Educational programs on basic financial literacy \\
\cline { 2 - 2 } & Educational programs on financial management \\
\cline { 2 - 2 } & Educational program on business development \\
\cline { 2 - 2 } & $\begin{array}{l}\text { Beneficial educational programs to help solve the } \\
\text { problems faced by the members }\end{array}$ \\
\hline \multirow{2}{*}{$\begin{array}{l}\text { Training Programs organized } \\
\text { by CU }\end{array}$} & Business development programs \\
\cline { 2 - 2 } & Business development programs are carried out routine \\
\hline
\end{tabular}




\begin{tabular}{|c|c|}
\hline & Providing funds for business development \\
\hline & Providing business assistance \\
\hline & Providing business facilities \\
\hline \multirow{4}{*}{$\begin{array}{l}\text { Empowerment programs } \\
\text { through savings and loans } \\
\text { Savings and loan }\end{array}$} & $\begin{array}{l}\text { Programs are intended for members at the initial } \\
\text { membership period }\end{array}$ \\
\hline & $\begin{array}{l}\text { CU member activities, especially in savings and loans } \\
\text { activities }\end{array}$ \\
\hline & $\begin{array}{l}\text { Various savings products (daily savings, time savings } \\
\text { /pension/inheritance, education savings, worship savings) }\end{array}$ \\
\hline & $\begin{array}{l}\text { Varied loan products (education loans, venture capital, } \\
\text { housing, vehicles) }\end{array}$ \\
\hline \multirow{3}{*}{$\begin{array}{l}\text { Network development } \\
\text { programs }\end{array}$} & $\begin{array}{l}\text { Holding programs that encourage members to build a } \\
\text { spirit of togetherness }\end{array}$ \\
\hline & $\begin{array}{l}\text { Members know well and have mutual understandings with } \\
\text { the CU management so that it is easy to get information } \\
\text { related to the CU programs }\end{array}$ \\
\hline & $\begin{array}{l}\text { Organizing activities and facilitating meetings of members } \\
\text { engaged in various business fields }\end{array}$ \\
\hline
\end{tabular}

\subsubsection{Member Welfare (WEALTH)}

Member Welfare in this study is defined as perception that a member gives of the economic improvement after becoming a member of the Credit Union. The welfare of members is measured using the following indicators, namely: (1) members' perceptions about the concern of $\mathrm{CU}$ on improving their welfare, (2) conflict resolution of economic problems faced by members, (3) programs to overcome members' business problems, and (4) positive impacts of CU for members.

\subsection{Research Model}

Hypothesis testing is carried out with the following regression equation:

Equation: WE $=\alpha+\beta_{1} \mathrm{EI}+\beta_{2} \mathrm{TI} \beta_{3} \mathrm{LI}+\beta_{4} \mathrm{NI}$

Where:
WE = Wealth
EI = Educational Program
$\mathrm{TI}=$ Training Program
LI = Savings and Loans Program
NI = Development of Network 


\section{RESULT AND DISCUSSION}

Descriptions of the data to be used in this study are shown in Table 1 below:

Table 1. Data Description of Each Variable

\begin{tabular}{l|c|c|c|c|c}
\hline & Mean & Median & Maximum & Minimum & Std. Dev. \\
\hline $\mathrm{EI}$ & 0.458967 & 0.428571 & 1.000 .000 & 0.142857 & 0.180060 \\
\hline $\mathrm{TI}$ & 0.472340 & 0.400000 & 1.000 .000 & 0.200000 & 0.224999 \\
\hline $\mathrm{LI}$ & 0.441489 & 0.400000 & 0.900000 & 0.000000 & 0.221631 \\
\hline $\mathrm{NI}$ & 0.597074 & 0.625000 & 1.000 .000 & 0.250000 & 0.177870 \\
\hline $\mathrm{WE}$ & 0.724632 & 0.730769 & 0.961538 & 0.192308 & 0.117678 \\
\hline
\end{tabular}

Source: The data source is processed

Based on Table 1 above, the amount of data analyzed were 94 from 15 different credit co-operatives in East Java. In this study, the empowerment program through education (EI) is a variable that has the lowest variation which is shown at the minimum value of 0.142857 and the maximum value of 1 and average of 0.458967 with a standard deviation of 0.18006 . Therefore, the DN variable data is then considered to be good enough to be processed statistically. The empowerment variable through training (IT) is a variable that has the minimum value of 0.2 and the maximum value of 0.9000 and an average of 0.472340 with a standard deviation of 0.224999 . Based on the description of the distribution, the standard deviation value is not large. Therefore, it is considered to be good enough to be processed statistically. Data for the empowerment variable through savings and loans (LI) has the minimum value of 0.00 , the maximum value of 0.9000 , and the average value of 0.441489 with a standard deviation of 0.221631 . Thus, the $\mathrm{LI}$ variable data is considered to be adequate to be processed statistically.

In the empowerment variable, cooperation $(\mathrm{NI})$ has a considerable number of variations. With the minimum value of 0.25 , the maximum value of 1 , and the average score of 0.597074 and the standard deviation of 0.177870 , the $\mathrm{NI}$ variable is considered to be adequate for statistical calculations.

\subsection{Results of Data Analysis}

The analysis is based on the research model arranged based on the proposed hypothesis. Hypothesis testing is done using equations that have previously been tested in classical assumptions namely Multicollinearity, heteroscedasticity and autocorrelation. The results of data analysis are as shown in Table 2 below: 
Table 2. Multicolinearity Test

\begin{tabular}{cccc}
\hline \hline Variable & $\begin{array}{c}\text { Coefficient } \\
\text { Variance }\end{array}$ & $\begin{array}{c}\text { Uncentered } \\
\text { VIF }\end{array}$ & $\begin{array}{c}\text { Centered } \\
\text { VIF }\end{array}$ \\
\hline \hline C & 0.001416 & 15.25697 & NA \\
EI & 0.003615 & 9.453205 & 1.249249 \\
$T I$ & 0.002367 & 6.966998 & 1.277306 \\
LI & 0.002117 & 5.555128 & 1.108645 \\
$\mathrm{NI}$ & 0.004185 & 17.48580 & 1.411370 \\
\hline \hline
\end{tabular}

Source: Source of data processed

In Table 2 above, it is shown that the coefficient of variance of El variables is at 1.249249 and that of IT variable is at1.277306, that of LI variable is 1.108645 and that of $\mathrm{NI}$ variable is at 1.411370 . In short, all variables have a smaller centered VIF of 10 , so there is no multicol.

Table 3. Heteroskedasticity Test

Heteroskedasticity Test: ARCH

\begin{tabular}{llll}
\hline \hline F-statistic & 0.183756 & Prob. F(1,91) & 0.6692 \\
Obs*R-squared & 0.187416 & Prob. Chi-Square(1) & 0.6651 \\
\hline \hline
\end{tabular}

Source: Sources of data processed

The dataset in Table 3 shows that the prob $F$ of 0.6692 is greater than 0.05 , so heteroscedasticity is said to not occur.

Table 4. Autocorrelation Test

Breusch-Godfrey Serial Correlation LM Test:

\begin{tabular}{llll}
\hline \hline F-statistic & 0.016695 & Prob. F(2,87) & 0.9834 \\
Obs*R-squared & 0.036062 & Prob. Chi-Square(2) & 0.9821 \\
\hline \hline
\end{tabular}

Source: Sources of data processed

In Table 4 above, it is shown that the prob $\mathrm{F}$ is 0.9834 , greater than 0.05 , which means that there is no autocorrelation. 
Table 5. Analysis of Multiple Linear Regression

\begin{tabular}{ccccc}
\hline \hline \multicolumn{1}{c}{ Variable } & Coefficient & Std. Error & t-Statistic & Prob. \\
\hline \hline C & 0.481434 & 0.037630 & 12.79387 & 0.0000 \\
El & 0.219173 & 0.060122 & 3.645493 & 0.0004 \\
TI & 0.172335 & 0.048651 & 3.542287 & 0.0006 \\
LI & 0.034473 & 0.046014 & 0.749194 & 0.4557 \\
& 0.077016 & 0.064690 & 1.190527 & 0.2370 \\
\hline \hline R-squared & 0.397102 & Mean dependent var & 0.724632 \\
Adjusted R-squared & 0.370005 & S.D. dependent var & 0.117678 \\
& & & & - \\
S.E. of regression & 0.093404 & Akaike info criterion & 1.852045 \\
& & & & - \\
Sum squared resid & 0.776460 & Schwarz criterion & 1.716763 \\
& & & & - \\
Log likelihood & 92.04611 & Hannan-Quinn criter. & 1.797401 \\
F-statistic & 14.65507 & Durbin-Watson stat & 1.953450 \\
Prob(F-statistic) & 0.000000 & & & \\
\hline \hline
\end{tabular}

Source: Processed data source

Based on Table 5 above, the data analyses produce a fit equation model where the statistical $\mathrm{F}$ probability value is 0.0000 less than $5 \%$, so the model can be used to test the hypotheses. In the research equation, the dependent variable is welfare (WE) and the independent variables include empowerment through education (EI), training from the government (IT), savings and loans (LI) and a network of cooperation (NI) shows an $\mathrm{R}^{2}$ of $39.7 \%$ with a stat $\mathrm{F}$ value of 0,000 . This means that the independent variables used are able to explain the welfare (WE) rate by $39.7 \%$. Although the independent variables of empowerment through savings (LI) and cooperation ( $\mathrm{NI}$ ) are not significant on Welfare (WE), the overall independent variables influence the dependent variable.

The results also show that Hypothesis 1 which states that "educational programs have positive effects on the welfare of members" is then accepted. This is indicated by the regression coefficient of the El variable to be 0.02 with a significance level of 0.0004 under a fault tolerance of $5 \%$. Therefore, it can be stated that the educational program has a significant positive effect on the welfare of members. Next, Hypothesis 2 which states that "the training program positively influences the welfare of members" is also accepted, because the regression coefficient of the IT variable was 0.17 with a significance level of 0.0006 under an error tolerance of $5 \%$. This shows that the training program has a significant positive effect on the welfare of members. Meanwhile for Hypothesis 3 which states that "the savings and loans program has a positive effect on the welfare of members" and Hypothesis 4 which states that "the network development program has a positive effect on the welfare of members" are both rejected. The regression 
coefficients of the $\mathrm{LI}$ and $\mathrm{NI}$ variables were 0.03 and 0.07 , but the significance level was above $5 \%$, each of 0.45 and 0.23 , respectively. Therefore, it can be stated that the savings and loans as well as network development program have no significant effect on the welfare of members.

The forms of empowerment in this research is divided into 4 namely, (1) empowerment through education, (2) empowerment through training, (3) empowerment through savings and loans and (4) empowerment through cooperation networks. The empowerment programs must be carried out together meaning that all the four activities must be simultaneously carried out. From the four empowerment programs in this study, the educational program and the training program had a significant positive effect on the increase of the welfare of members, while the savings and loan program as well as the network building program did not significantly affect the welfare of members. This is possible because members who have networks and receive funding assistance will not succeed without a good education and training. This explains why education and training programs have more influence on the welfare of CU members compared to savings and loan programs and network development programs.

\section{CONCLUSION}

This study aims to determine the effect of empowerment programs on the welfare of members. The empowerment program is divided into educational programs, training programs, savings and loan programs and development programs. The results showed that the empowerment program through educational programs and training programs had significantly positive effects on the increase of the welfare of members while the savings and loans program and the network building program did not significantly affect the welfare of members. This is possible because members who have networks and receive funding assistance will not succeed without good education and training.

\section{REFERENCE}

Baswir Revrisond. 2000. Koperasi Indonesia. Yogyakarta: BPFE-Yogyakarta

Gitman, L.J. and Zutter, C.J. 2012. Principles of Managerial Finance, 13th Edition, Prentice Hall.

Hudiyanto, Sistem Koperasi, Ideologi dan Pengelolaan, Yogyakarta : UII Pres, 2001

Horne, V.J.C and Wachowicz, J.M. 2009. Prinsip-prinsip Manajemen Keuangan. Jakarta: Salemba Empat.

http://puskopditbag.org/wp-content/uploads/2014/06/ANALISIS-PEARLS.ppt 
KOMPAS, 14 Desember 2007, 'Usaha Mikro: Akselerasi Pembiayaan UMKM’ oleh Djoko Retnadi.

KOMPAS, 29 Februari 2008, 'Fokus: Masalah Besar di Usaha Kecil'.

Munaldus., Y.K., Yohanes, R.J., Hendi, B., 2013, Hidup Berkelimpahan Bersama Credit Union, PT Elex Media Komputindo, Jakarta.

Partomo, S.T., 2009, Ekonomi Koperasi, Cetakan I, Ghalia Indonesia, Ciawi-Bogor.

Richardson, D.C., 2009, WOCCU PEARLS Monitoring System fromfile:///C:/Users/User/Downloads/pearls_mono-graph.pdf

Sulistiyani, A.T.(2004). Kemitraan dan Model-Model Pemberdayaan. Yogyakarta: Gava Media.

Undang-undang Nomor 25 Tahun 1992 Tentang Pokok-pokok Perkoperasian 